\title{
Report on Guantánamo Detainees: A Profile of 517 Detainees Through Analysis of Department of Defense Data
}

\author{
Mark Denbeaux* \\ Joshua Denbeaux* \\ David Gratz \\ John Gregorek \\ Matthew Darby \\ Shana Edwards \\ Shane Hartman \\ Daniel Mann \\ Megan Sassaman \\ Helen Skinner
}

\section{INTRODUCTION ${ }^{1}$}

As of February 2006, the U.S. government held more than 500 individuals at Guantánamo Bay as alleged "enemy combatants." In

\footnotetext{
Professor, Seton Hall University School of Law, and Director, Seton Hall University School of Law Center for Policy and Research.

Partner, Denbeaux \& Denbeaux. Co-authors Professor Mark Denbeaux and Joshua Denbeaux represent two Guantánamo detainees. This report also benefited from the research and contributions of Grace Byrd, Christopher Fox, Jillian Gautier, Doug Eadie, Mark Muoio, Courtney Ray, Laura Sims and Lauren Winchester.

${ }_{1}$ This Report, originally published on February 8, 2006, used government data obtained from Freedom of Information Act (FOIA) litigation to profile over 517 detainees held at Guantánamo. The primary sources used were the Combatant Status Review Tribunal (CSRT) files. See discussion infra Part II for more on the CSRTs. Since this Report's initial publication, the detainee population at Guantánamo has been reduced to 171. The Guantánamo Docket, N.Y. Times, http://projects.nytimes.com/guantanamo/detainees/held (last visited Sept. $27,2011)$. In addition, more information has been made available through later government releases and WikiLeaks. This Report was not updated based on WikiLeaks. For future reports by the Seton Hall University School of Law Center for Policy and Research (the "Center"), visit the Center's website at http://law.shu.edu/ProgramsCenters/PublicIntGovServ/policyresearch/Guantan amo-Reports.cfm.

${ }^{2}$ Combatant Status Review Tribunals (CSRT) and Administrative Review Board (ARB) Documents, U.S. DEP'T OF http://www.dod.mil/pubs/foi/operation_and_plans/Detainee/csrt_arb/index.html (last visited Sept. 27, 2011) [hereinafter CSRT]. The original government released files used for this Report are on file with the author at the Center. The above
} 
attempting to defend the necessity of the Guantánamo detention camp, the government routinely referred to this group as "the worst of the worst" of the government's enemies." The government had detained most of these individuals for more than four years; yet only ten, approximately, were charged with any violations of the laws of war. ${ }^{4}$ The rest remained detained based on the government's own conclusions, without the prospect of a trial or judicial hearing. ${ }^{5}$ During these lengthy detentions, the government had sufficient time to conclude whether, in fact, these men were enemy combatants and to document its rationale.

On March 28, 2002, in a Department of Defense briefing, Secretary of Defense Donald Rumsfeld said:

As has been the case in previous wars, the country that takes prisoners generally decides that they would prefer them not to go back to the battlefield. They detain those "enemy combatants" for the duration of the conflict. They do so for the very simple reason, which I would have thought is obvious_—namely to keep them from going right back and in this case killing more Americans and conducting more terrorist acts. ${ }^{6}$

This Report concludes, however, that the large majority of detainees never participated in any combat against the United States on a battlefield. Therefore, while setting aside the significant legal and constitutional issues at stake in federal Guantánamo habeas litigation, this Report merely addresses the factual basis underlying the public representations regarding the status of the Guantánamo detainees as made in 2006.

sources, released after this Report's initial publication, contain the data relevant to this Report and also include new data such as detainee names and Internment Serial Numbers (ISNs).

${ }^{3}$ See Joseph Margulies, A Year and Holding, Limbo is No Place to Detain Them, WASH. Post, Dec. 22, 2002, at B1 ("Rear Adm. John D. Stufflebeem, deputy director of operations for the Joint Chiefs of Staff, said: 'They are bad guys. They are the worst of the worst, and if let out on the street, they will go back to the proclivity of trying to kill Americans and others."”).

${ }^{4}$ Peter Finn, Guantanamo Detainee Faces Capital Charges in Cole Attack, WASH. PoST, Apr. 21, 2011, at A3.

${ }^{5}$ Since initial publication, the Supreme Court of the United States held that the detainees at Guantánamo are entitled to file habeas petitions and to participate in hearings. See Boumediene v. Bush, 553 U.S. 723 (2008).

${ }^{6}$ Donald Rumsfeld, Sec'y of Def., Department of Defense News BriefingSecretary Rumsfeld and General Myers (Mar. 28, 2002), available at http://www.defense.gov/transcripts/transcript.aspx?transcriptid=3380; see also Katherine Q. Seelye, Threats and Responses: The Detainees; Some Guantanamo Prisoners Will Be Freed, Rumsfeld Says, N.Y. Times, Oct. 23, 2002, at A14. 
Part II of this Report describes the sources and limitations of the data analyzed here. Part III describes the government's "findings." These "findings" constitute the government's determination that the individual in question was an enemy combatant. The government made this determination based on its classifications of terrorist groups, asserted connections between the individual and the purported terrorist groups, and the commission of "hostile acts," if any, that the government determined that the individual committed. Part IV then examines the evidence, including sources for such evidence, upon which the government relied in making these findings. Part $\mathrm{V}$ addresses the continued detention of individuals deemed not to be enemy combatants by comparing the government's allegations against such persons to similar or more serious allegations against persons still deemed to be "enemy combatants."

\section{THE DATA}

This Report examines data from written determinations that the government produced in 2006 for the detainees designated as "enemy combatants." The government prepared these written determinations following the military hearings, known as Combatant Status Review Tribunals (CSRTs), which commenced in 2004 and were designed to ascertain whether a detainee should continue to be classified as an "enemy combatant." ${ }^{8}$ The data are limited for a number of reasons. The data are framed in the government's terms and, as such, are no more precise than the government's categories permit. In addition, the charges were anonymous in the sense that the summaries upon which this Report relies did not identify by name or Internment Serial Number (ISN) any of the prisoners. ' It was therefore not possible to determine which summary applied to which prisoner at the time the Report was compiled.

Within these limitations, however, the data were very powerful because they set forth the government's publically released case for the status of the individuals. This Report assumes that the information contained in the CSRT summaries of evidence was an accurate description of the evidence relied upon by the government to conclude that each prisoner was an enemy combatant. The government

\footnotetext{
${ }^{7}$ See CSRT, supra note 2.

8 David L. McColgin, Editorial, Guantanamo: Five Years and Counting, PITTSBurgh Post-Gazette (Pa.), Mar. 4, 2007, at H-1.

${ }^{9}$ Names and ISNs are now available through government releases. This does not change the findings of this Report, and later reports by the Center analyze more recent government releases.
} 
filed these summaries against each individual detainee in advance of each detainee's CSRT hearing.

\section{THE GOVERnMENT'S FINDINGS OF ENEMY COMBATANT STATUS}

\section{A. Structure of the Government's Findings}

For each detainee deemed an "enemy combatant," the government provided a summary of evidence. Each summary contained the following sentence: "The United States Government has previously determined that the detainee is an "enemy combatant." "10 This "determination [was] based on information possessed by the United States that indicate[d] that [the detainee qualified for his designation]." ${ }^{11}$ Since the government had "previously determined" that each detainee at Guantánamo Bay was an "enemy combatant" before the CSRT hearing, the "summary of evidence" released by the government is not the government's allegations against each detainee; rather, it is a summary of the government's proofs upon which the government based its determination.

Each summary of evidence has four numbered paragraphs. The first $^{12}$ and fourth $^{13}$ paragraphs are jurisdictional in nature. The second paragraph state the government's definition of "enemy combatant" for purposes of the CSRT proceedings. ${ }^{14}$ The third paragraph

${ }^{10}$ See e.g., Memorandum from OIC, CSRT on Summary of Evidence for Combatant Status Review Tribunal-Hicks, David Mathew to Pers. Representative at 1, Hicks v. United States, No. 02-CV-0299 (D.D.C. Oct. 1, 2004) [hereinafter, Summary, Hicks], available

http://www.dod.mil/pubs/foi/operation_and_plans/Detainee/csrt_arb/publicly_fil ed_CSRT_records_1-91.pdf.

${ }^{11} I d$.

${ }^{12}$ See, e.g., id. ("Under the provisions of the Deputy Secretary of Defense Memorandum, dated 14 July 2006, Implementation of Combatant Status Review Tribunal Procedures for Enemy Combatants Detained at U.S. Naval Base Guantanamo Bay, Cuba, a Tribunal has been appointed to determine if the detainee is an enemy combatant.").

${ }^{13}$ See, e.g., id. at 2.

The detainee has the opportunity to contest his designation as an enemy combatant. The Tribunal will endeavor to arrange for the presence of any reasonably available witnesses or evidence that the detainee desires to call or introduce to prove that he is not an enemy combatant. The Tribunal President will determine the reasonable availability and relevance of evidence or witnesses.

$I d$.

${ }^{4}$ See, e.g., id. at 1. An enemy combatant has been defined as "an individual who was part of or supporting the Taliban or al Qaida forces, or associated forces that are engaged in hostilities against the United States or its coalition partners. This includes any person who committed a belligerent act or has directly supported hostilities in aid of enemy forces." Id. (emphasis added). 
summarizes the evidence that convinced the government that each detainee was an "enemy combatant." ${ }^{15}$ Paragraph 3(a) is the government's determination of the detainee's relationship with a "defined terrorist organization." ${ }^{16}$ Paragraph 3(b) explains the government's finding that a detainee had or had not committed "hostile acts" against the United States or coalition forces. ${ }^{17}$ In $55 \%$ of the reports, the government concluded that the detainee had not committed such an act and omitted the entire paragraph 3(b) section from the CSRT summary. Forty-five percent of the time, the government concluded that the detainee had committed paragraph $3(\mathrm{~b})$ hostile acts against United States or coalition forces and in these cases there is a paragraph 3(b) in the CSRT summary to that effect. For those detainees whose CSRT summaries include a 3(b) finding, the government listed its specific findings "proving" the existence of the hostile acts in a brief series of sub-paragraphs. Of those CSRT summaries that contain a paragraph 3(b) "hostile acts" determination, the mean number of sub-paragraphs was two. That is, in the CSRT summaries of the $45 \%$ of detainees who allegedly committed 3(b) hostile acts, the government cited an average of two pieces of evidence for its conclusions. Fewer than $2 \%$ of all 517 CSRT summaries contained more than five 3(b) sub-paragraphs, whereas the vast majority contained one and three such "proofs" of hostile acts.

\section{B. The Definition of Enemy Combatant}

For the purposes of the CSRT, an "enemy combatant" is defined as "an individual who was part of or supporting the Taliban or al Qaida forces, or associated forces that are engaged in hostilities against the United States or its coalition partners. This includes any person who committed a belligerent act or has directly supported hostilities in aid of enemy forces."

${ }^{15}$ See, e.g., id. at 1-2.

${ }^{16}$ See discussion infra Part IV.A. Many of the "defined terrorist organizations" referenced in the CSRT summaries of evidence are not considered terrorist organizations by the Department of Homeland Security. For a May 2011 list of designated foreign terrorist organizations, see Current List of Designated Foreign Terrorist Organizations, U.S. DEP'T OF STATE, http://www.state.gov/s/ct/rls/other/des/123085.htm (last updated Sept. 15, 2011).

7 See, e.g., Summary, Hicks, supra note 10, at 1-2.

18 See, e.g., id. at 3. The definition of "enemy combatant" for the purpose of Guantánamo detainment has evolved. In January 2002, when the first detainees were sent from Pakistan and Afghanistan to Cuba, they were termed, as were the detainees in Ex parte Quirin, "unlawful belligerents." 317 U.S. 1, 35 (1942). In Hamdi v. Rumsfeld, the government defined "enemy combatant" far more narrowly as someone who was " "part of or supporting forces hostile to the United States or coalition partners' 
This could be interpreted as requiring either that a combatant be both a member of a prohibited group and engaged in hostilities against the United States or coalition forces or, alternatively, that a combatant be either a member of a prohibited group or engaged in hostilities against the United States or coalition forces. Indeed, under this definition, one could be detained for an undefined level of "support" to groups considered hostile to the United States or its coalition forces.

\section{Categories of Evidence Supporting Enemy Combatant Designation}

The government divided the evidence against detainees into two sections: a paragraph $3(\mathrm{a})$, nexus with prohibited organizations, and a paragraph 3(b), participation in military operations or commission of hostile acts. $^{19}$ Paragraph 3 always begins with the allegation that each detainee met all the requirements contained in the definition of paragraph $2 .{ }^{20}$ More often than not, the government found that the detainees did not commit the alleged hostile or belligerent acts.

in Afghanistan and who 'engaged in an armed conflict against the United States' there." 542 U.S. 507, 516 (2004). Later, in response to Rasul v. Bush, 542 U.S. 466 (2004), the detainees were called "enemy combatants."

In February 2004, Secretary of Defense Rumsfeld said:

The circumstances in which individuals are apprehended on the battlefield can be ambiguous, as I'm sure people here can understand. This ambiguity is not only the result of the inevitable disorder of the battlefield, it is an ambiguity created by enemies who violate the laws of war by fighting in civilian clothes, by carrying multiple identification documentations, by having three, six, eight, in one case 13 different aliases. ... Because of this ambiguity, even after enemy combatants are detained, it takes time to check stories, to resolve inconsistencies or, in some cases, even to get the detainee to provide any useful information to help resolve the circumstance.

Donald Rumsfeld, Sec'y of Def., Address to the Miami Chamber of Commerce (Feb. 13, 2004), available at http://transcripts.cnn.com/transcripts/0402/13/se.02.html).

On August 13, 2004, Gordon England, Secretary of the Navy, and Secretary Rumsfeld's designee for the tribunal process at Guantánamo, stated that " $[t]$ he definition of an enemy combatant is in the implementing orders, which have been passed out to everyone. But in short, it means anyone who is part of supporting the Taliban or al Qaeda forces or associated forces engaging in hostilities against the United States or our coalition partners." Gordon England, Sec'y of the Navy, Special Defense Department Briefing on Combatant Status Review Tribunals (Aug. 13, 2004), available at http:/ /www.defense.gov/transcripts/transcript.aspx?transcriptid=2560.

19 See, e.g., Summary, Hicks, supra note 10, at 1.

${ }^{20}$ See, e.g., id. 
1. Paragraph 3(a): Enemy Combatant Based on Nexus with Prohibited Organization

\section{a. Definition of Prohibited Organizations}

The data reveal that the government divided a detainee's enemycombatant status into six distinct categories that describe the terrorist organization with which the detainee was affiliated. ${ }^{21}$ A breakdown of the data based on the representation of each group is as follows:

- al Qaeda (32\%)

- al Qaeda and Taliban (28\%)

- Taliban $(22 \%)$

- al Qaeda or Taliban (7\%)

- Unidentified Affiliation (10\%)

- Other $(1 \%)$

The CSRT summary of evidence provides no way to determine the difference between the "Unidentified Affiliation" and "Other" categories and no explanation as to why there are separate categories for "al Qaeda and Taliban" and "al Qaeda or Taliban." If, after four years of detention, the government was unable to determine whether a detainee was affiliated with either al Qaeda or the Taliban, then it is reasonable to conclude that the government did not have evidence of the detainee's affiliation. Under this assumption, the data reveal that $40 \%$ of the detainees were not affiliated with al Qaeda and $18 \%$ of the detainees were not affiliated with either al Qaeda or the Taliban.

b. Nexus with the Identified Organization

The data explain that the government generally ascribed to a detainee one of three degrees of connection between the detainee and the organization with which he was allegedly affiliated. The government classified detainees as either "fighters for," "members of," or "associated with" a particular terrorist organization. The data illustrate that, regardless of the group to which they were connected, by far the greatest number of prisoners were identified only as being "associated with" one group or another. The government identified a

${ }^{21}$ See e.g., Memorandum from OIC, CSRT on Summary of Evidence for Combatant Status Review Tribunal-Detainee Ruhani, Gholam to Pers. Representative at 1, Ruhani v. Bush, No. 05-2367 (D.D.C. Aug. 10, 2006), available at http://www.dod.mil/pubs/foi/operation_and_plans/Detainee/csrt_arb/publicly_fil ed_CSRT_records_1-91.pdf (Taliban); Memorandum from OIC, CSRT on Summary of Evidence for Combatant Status Review Tribunal-Wasiq, Abdul Haq to Pers. Representative at 1, Wasiq v. Bish, No. 05-2386 (D.D.C. Aug. 11, 2006), available at http://www.dod.mil/pubs/foi/operation_and_plans/Detainee/csrt_arb/publicly_fil ed_CSRT_records_1-91.pdf (al Qaeda and Taliban). 
much smaller percentage-30\%—as "members of." Only $8 \%$ were classified as "fighters for."

The definition of "fighters for" seems to be obvious, while definitions of "members of" and "associated with" are less clear and could justify a very broad level of attenuation. According to Evan Kohlman, the government's expert on al Qaeda membership, simply being told that one had been selected as a member would qualify one as a member:

[A]l-Qaeda leaders could dispatch one of their own-someone who is not top tier ... to recruit someone and to tell them [sic], I have been given a mandate to do this on behalf of senior al-Qaeda leaders... even though perhaps this individual has never sworn an official oath and this person has never been to an al-Qaeda training camp, nor have they [sic] actually met, say, Osama bin Ladin. $^{22}$

This expansive definition of membership in al Qaeda could thus be applied to anyone who the government believes has ever spoken to an al Qaeda member. Even under this broad framework, the government concluded that a full $60 \%$ of the detainees did not have this minimal level of contact with an al Qaeda member.

Membership in the Taliban is different and not clearly defined. According to the government, one could be a conscripted-and therefore possibly unwilling-member of the Taliban and still be an enemy combatant. ${ }^{23}$ Comparing the nexus between enemy combatants with al Qaeda and the Taliban yields a different result. The "al Qaeda only" category shows that a large percentage of detainees were "associated with" $(57 \%)$ or "members of" $(34 \%)$, while only $9 \%$ were "fighters for." In contrast to the "al Qaeda only" category, the "Taliban only" category showed that the government designated a significantly higher percentage of the prisoners as "members of" $(48 \%)$ and "fighters for," (16\%) with fewer labeled "associated with" (36\%). Moreover, 78\% of the prisoners identified as both "al Qaeda and Taliban" were merely "associated with," $19 \%$ were "members of," and $3 \%$ were "fighters for." When the government could not specifically identify a detainee as a member of either al Qaeda or the Taliban, the degree of connection attributed to such detainees seems tenuous.

${ }^{22}$ Transcript of Record at 113, United States v. Paracha, No. 03-cr-01197 (S.D.N.Y. Nov. 9, 2005).

${ }^{23}$ See, e.g., Unclassified Summary of Basis for Tribunal Decision at 2, Al Murbati v. Bush, 04-CV-1227 (D.D.C. Oct. 12, 2004) [hereinafter Summary, Al Murbati], available

http://www.dod.mil/pubs/foi/operation_and_plans/Detainee/csrt_arb/publicly_fil ed_CSRT_records_444-565.pdf. 
The government's summaries of evidence recognize that more often than not members of the Taliban were not members of al Qaeda. The government categorized more than $54 \%$ of the detainees as exclusively members of al Qaeda or exclusively members of the Taliban, and only $28 \%$ of the detainees as members of both. The data provided no explanation for the explicit distinction between those persons identified as being connected to "al Qaeda and the Taliban" as opposed to "al Qaeda or the Taliban."

2. Paragraph 3(b): The Government's Findings on

Detainees' 3(b) Hostile Acts Against the United States or Coalition Forces

Although the government's public position was that these detainees were "the worst of the worst," government had already concluded that a majority of those who continued to be detained at Guantánamo had no history of any 3(b) hostile acts against the United States or its allies. According to the government, fewer than half of the detainees engaged in 3(b) hostile acts against the United States or any members of its coalition. This is true even though the government's definition of a 3(b) hostile act was not demanding. For example, the government determined that the following evidence was sufficient to constitute a 3 (b) hostile act:

The detainee participated in military operations against the United States and its coalition partners.

1. The detainee fled, along with others, when the United States' forces bombed their camp.

2. The detainee was captured in Pakistan, along with other Uighur fighters. ${ }^{25}$

Cross-analyzing the paragraph 3(a) and 3(b) data shows that individuals in some groups were less likely to have committed hostile acts than those in others. In the "al Qaeda or Taliban" group, for example, $71 \%$ of the detainees had not been found to have committed any hostile act. Of the "other" detainees, the $18 \%$ whose 3 (a) nexus was either "Unidentified Affiliation," "al Qaeda or Taliban," or "Other," only $24 \%$ were determined to have committed a 3 (b) hostile act.

It is possible that the less clear the government's characterization of a detainee's affiliation with a prohibited group was, the less

${ }^{24}$ See Margulies, supra note 3.

${ }_{25}$ Memorandum from OIC, CSRT on Summary of Evidence for Combatant Status Review Tribunal-Abbas, Yusef to Pers. Representative [hereinafter, Abbas, Summary], available at http://www.dod.mil/pubs/foi/ operation_and_plans/Detainee/csrt_arb/000300-000399.pdf. 
likely the detainee was to have committed a hostile act. This is particularly notable because the percentage of detainees whom the government could not clearly connect to a prohibited group was so large. ${ }^{26}$

The same pattern holds true when the degree of connection between the detainee and the affiliated group lessens: $32 \%$ of the detainees were designated exclusively as "al Qaeda" and 57\% of those detainees were described as "associated with" al Qaeda. Of those $57 \%$ who are merely "associated with" al Qaeda, $72 \%$ had not committed 3(b) hostile acts. Thus, the data illustrate that not only were the majority of the al Qaeda detainees merely "associated with" al Qaeda, but also that the government concluded that a substantial number of those detainees did not commit 3(b) hostile acts.

\section{THE GOVERnMENT'S EVIDENCE THAT THE DETAINEES WERE ENEMY COMBATANTS}

The data provide at least some answers to two important questions: How was the evidence of the detainees' enemy-combatant status obtained? And, what evidence did the government have as to the detainees' commission of 3(b) violations?

Pakistan was the source of at least $36 \%$ of all detainees, and the Afghanistan Northern Alliance was the source of at least $11 \%$. The pervasiveness of Pakistani involvement is made clear by the fact that of the $56 \%$ of detainees whose captor was identified, $66 \%$ were captured in Pakistan or by Pakistani authorities. Thus, if $66 \%$ of the unknown $44 \%$ were also captured in Pakistan, the total number of detainees captured in Pakistan or by Pakistani authorities would be $66 \%$.

Since the government presumably knew which detainees were captured by U.S. forces, it is safe to assume that those whose captors were not known were captured by some third party. The conclusion drawn from the government's evidence is that $93 \%$ of the detainees were not apprehended by U.S. forces. Hopefully, in assessing the "enemy combatant" status of such detainees, the government appropriately addressed the reliability of information provided by the third parties who turned over detainees; yet the data provides no assurances that the government employed any proper safeguards against mistaken identification.

${ }^{26}$ The "Others"-accounting for $18 \%$ of the total-is comprised of "al Qaeda or Taliban" (7\%), Unidentified Affiliation" (10\%), and “Other" (1\%). 
The U.S. government promised-and presumably paid-large sums of money for the capture of persons identified as enemy combatants in Afghanistan and Pakistan. One representative flyer, distributed in Afghanistan, stated:

Get wealth and power beyond your dreams .... You can receive millions of dollars helping the Anti-Taliban Force catch al-Qaeda and Taliban murderers. This is enough money to take care of your family, your village, your tribe for the rest of your life-pay for livestock and doctors and school books and housing for all your people. ${ }^{27}$

Bounty hunters or reward seekers handed people over to American or Northern Alliance soldiers in the field, often disappearing soon after; ${ }^{28}$ as a result, there was little opportunity in the field to verify the story of an individual who presented the detainee in order to receive the bounty award. Where that story constitutes the sole basis for an individual's detention at Guantánamo, there would be limited ability by either the government to corroborate or by a detainee to successfully refute such an allegation.

One example of the government finding detainees to be enemy combatants based on information from bounty hunters was the capture of the Uighurs. In the Uighurs' case, there was little doubt that the government paid bounties for the capture and detainment of individuals who were not enemy combatants. ${ }^{29}$ At the time when this Report was written, the Uighurs had yet to be released. ${ }^{30}$

The government's evidence against some of the detainees was formidable. In those cases, the government's evidence portrayed the detainees as powerful, dangerous, and knowledgeable men who enjoyed positions of considerable power within the terrorist organizations. The evidence against them was concrete and plausible. The evidence provided for most of the detainees, however, was far less convincing.

The summaries of evidence against this small number of detainees indicated that they played important roles in al Qaeda. This

${ }^{27}$ Herbert A. Friedman, Psychological Operations in Afghanistan, AFG. PSYOP LEAFLET, http:/ /www.psywarrior.com/Herbafghan02.html (last visited Oct. 5, 2011).

${ }_{28}$ See, e.g., Jonathan Mahler, The Bush Administration vs. Salim Hamdan, N.Y. Times, Jan. 8, 2006, §6 (Magazine), at 44.

${ }_{29}$ Josh White \& Robin Wright, Detainee Cleared for Release is in Limbo at Guantanamo, WASH. Post, Dec. 15, 2005, at A9.

${ }^{30}$ Currently, there are only five remaining Uighurs detained at Guantánamo. Editorial, Every Zone, WASH. POST, May 24, 2011, at A20 (“[T] he five remaining Chinese Uighurs, have been cleared for release but cannot be returned to their home country for fear of mistreatment."). 
evidence, on its face, seems reliable. For instance, the government found that $11 \%$ of the detainees met with Osama bin Laden. Other examples included:

- a detainee who allegedly drove a rocket launcher to combat against the Northern Alliance; ${ }^{31}$

- a detainee who held a high-ranking position in the Taliban and who tortured, maimed, and murdered Afghan nationals held in Taliban jails; ${ }^{32}$

- a detainee who was present and participated in al Qaeda meetings discussing the September 11, 2001, attacks before they occurred; ${ }^{33}$

- a detainee who produced al Qaeda propaganda, including the video commemorating the U.S.S. Cole attack; ${ }^{34}$

- a detainee who was a senior al Qaeda lieutenant; ${ }^{35}$

- eleven detainees who swore an oath to Osama Bin Laden. ${ }^{36}$

The examples above are atypical of the CSRT summaries. The government's evidence alleged that only a few detainees were ever ac-

31 See, Memorandum from Recorder on Summary of Evidence for Combatant Status Review Tribunal-Sayaf al Habiri to Pers. Representative, Mishal Awad, available at http://www.dod.mil/pubs/foi/operation_and_plans/Detainee/csrt_arb/000201000299.pdf.

${ }^{32}$ See, Memorandum from OIC, CSRT on Summary of Evidence for Combatant Status Review Tribunal-Rahman, Shed Abdur to Pers. Representative (Sept. 4, 2004), available

http://www.dod.mil/pubs/foi/operation_and_plans/Detainee/csrt_arb/000500000599.pdf.

${ }_{33}$ See, Memorandum from Recorder on Summary of Evidence for Combatant Status Review Tribunal-Al Zahri, Abdul al Rahman to Pers. Representative (Aug. 8, 2004), available

http://www.dod.mil/pubs/foi/operation_and_plans/Detainee/csrt_arb/000400000499.pdf.

${ }^{34}$ See, Memorandum from OIC, CSRT on Summary of Evidence for Combatant Status Review Tribunal-Al Mishad, Sharif Fati Ali to Pers. Representative (Dec. 8, 2004), available

http://www.dod.mil/pubs/foi/operation_and_plans/Detainee/csrt_arb/000101000200.pdf.

${ }^{35}$ See, Memorandum from OIC, CSRT on Summary of Evidence for Combatant Status Review Tribunal-Husayn, Zayn Al Abidin Muhammad [Abu Zabayadah] to Pers. Representative (Mar. 19, 2007), available at http://www.dod.mil/pubs/foi/operation_and_plans/Detainee/csrt_arb/000784000819.pdf.

${ }^{36}$ See, e.g., Memorandum from OIC, CSRT on Summary of Evidence for Combatant Status Review Tribunal-Detainee Al Bahlul, Ali Hamza Ahmed Suleiman to Pers. Representative(Sept. 7, 2004), available at http://www.dod.mil/pubs/foi/operation_and_plans/Detainee/csrt_arb/000001000100.pdf. 
tually engaged in activities for al Qaeda or the Taliban. The eleven detainees who swore an oath to Osama Bin Laden, for example, were only a fraction of the total number of the detainees at Guantánamo.

The Taliban was a different story. The Taliban was a religious state that demanded the most extreme compliance of all of its citizens and, as such, controlled all aspects of their lives through pervasive governmental and religious operation. ${ }^{37}$ Under Mullah Omar, the leader of the Taliban and Afghanistan's de facto head of state from 1996 to 2001, there were eleven governors and various ministers who dealt with issues such as permitting journalists to travel and overseeing the dealings between the Taliban and non-governmental organizations in Afghanistan for United Nations aid projects. ${ }^{38}$ By 1997, all international "aid projects had to receive clearance not just from the relevant ministry, but also from the ministries of Interior, Public Health, Police, and the Department of the Promotion of Virtue and Prevention of Vice." ${ }^{39}$ There was a Health Minister, Governor of the State Bank, an Attorney General, an Education Minister, and an AntiDrug Control Force. ${ }^{40}$ Each city had a mayor, chief of police, and senior administrators. ${ }^{41}$ None of these individuals were at Guantánamo Bay. The Taliban detainees seemed to be people not responsible for actually running the country. Many of the detainees held at Guantánamo were involved with the Taliban unwillingly as conscripts or otherwise.

General conscription was the rule, not the exception, in Taliban controlled Afghanistan. ${ }^{42}$ As explained, "all the warlords had used boy soldiers, some as young as 12 years old, and many were orphans with no hope of having a family, or education, or a job, except soldiering."

Just as strong evidence proves much, weak evidence suggests more. Examples of evidence that the government cited as proof that the detainees were enemy combatants included:

\footnotetext{
37 See generally Ahmed Rashid, Taliban: Militant IsLam, Oil and Fundamentalism IN CENTRAL ASIA (2001).

38 Id. at 99.

${ }^{39} \quad I d$. at 114.

${ }^{40} I d$.

${ }^{41} \quad I d$.

${ }^{42} I d$. at 100.

${ }^{43}$ RASHID, supra note 37 , at 109.
} 
- associations with unnamed and unidentified individuals or organizations; ${ }^{44}$

- associations with organizations, the members of which would be allowed into the United States by the Department of Homeland Security;

- possession of rifles; ${ }^{46}$

- use of a guest house;

- possession of Casio watches; and ${ }^{48}$

- $\quad$ wearing olive drab clothing. ${ }^{49}$

The following is an example of the entire publically available record for a detainee who was conscripted into the Taliban:

a.Detainee is associated with the Taliban

1. The detainee indicates that he was conscripted into the Taliban.

b. Detainee engaged in hostilities against the U.S. or its coalition partners.

${ }^{44}$ See, e.g., Memorandum from OIC, CSRT on Summary of Evidence for Combatant Status Review Tribunal-Shalehove, Maroof, Saleemovich to Pers. Representative (Dec. 8, 2005), available http://www.dod.mil/pubs/foi/operation_and_plans/Detainee/csrt_arb/000201000299.pdf.

45 See, e.g., Memorandum from OIC, CSRT on Summary of Evidence for Combatant Status Review Tribunal-Amin, Omar Rajab to Pers. Representative (Sept 22, 2004), available

http://www.dod.mil/pubs/foi/operation_and_plans/Detainee/csrt_arb/000001000100.pdf.

${ }^{46}$ See, e.g., Memorandum from OIC, CSRT on Summary of Evidence for Combatant Status Review Tribunal-Ami, Shakir Abdurahim Mohamed to Pers. Representative (Nov. 19, 2004), available at http://www.dod.mil/pubs/foi/operation_and_plans/Detainee/csrt_arb/000201000299.pdf.

${ }^{47}$ See, e.g., Memorandum from OIC, CSRT on Summary of Evidence for Combatant Status Review Tribunal-Salam, Mohammed Ahmed to Pers. Representative (Oct. 24, 2004), available at http://www.dod.mil/pubs/foi/operation_and_plans/Detainee/csrt_arb/000500000599.pdf.

${ }^{48}$ See, e.g., Memorandum from OIC, CSRT on Summary of Evidence for Combatant Status Review Tribunal-Sulayman, Abdul Rahman Abdul Abu Giyth to Pers. Representative (Oct. 12, 2004), available at http://www.dod.mil/pubs/foi/operation_and_plans/Detainee/csrt_arb/000201000299.pdf.

${ }_{49}$ See, e.g., Memorandum from OIC, CSRT on Summary of Evidence for Combatant Status Review Tribunal-Yar, Kushky to Pers. Representative (Nov. 10, 2004), available http://www.dod.mil/pubs/foi/operation_and_plans/Detainee/csrt_arb/000600000699.pdf. 
1. The detainee admits he was a cook's assistant for Taliban forces in Narim, Afghanistan under the command of Haji Mullah Baki. 2. Detainee fled from Narim to Kabul during the Northern Alliance attack and surrendered to the Northern Alliance. ${ }^{50}$

The government classified other detainees as enemy combatants because of their association with unnamed individuals. A typical example of such evidence is the following:

1. The detainee is associated with forces that are engaged in hostilities against the United States and its coalition partners:

2. The detainee voluntarily traveled from Saudi Arabia to Afghanistan in November 2001.

3. The detainee traveled and shared hotel rooms with an Afghani.

4. The Afghani that the detainee traveled with is a member of the Taliban Government.

5. The detainee was captured on December 10, 2001, on the border of Pakistan and Afghanistan. ${ }^{51}$

The government deemed some of these detainees enemy combatants based on their association with identified organizations that the Department of Homeland Security (DHS) did not prohibit from entering the United States. In analyzing the charges against the detainees, the Combatant Status Review Board identified seventy-four organizations that were used to demonstrate links between the detainees and al Qaeda or the Taliban. These seventy-four organizations were compared to the list of Foreign Terrorist Organizations in the Terrorist Organization Reference Guide ("Reference Guide") of the U.S. Department of Homeland Security, U.S. Customs and Border Protection, and the Office of Border Patrol. ${ }^{52}$ The DHS published the Reference Guide in January 2004, which was the same year in which the charges were filed against the detainees. According to the Reference Guide, the purpose of the list is "to provide the Field with a who's who in terrorism." Th3 Those seventy-four foreign terrorist organizations are classified in two groups: thirty-six "designated foreign

\footnotetext{
${ }^{50}$ Summary, Al Murbati, supra note 23, at 2.

${ }^{51}$ See, e.g., Memorandum from OIC, CSRT on Summary of Evidence for Combatant Status Review Tribunal-Al Rushaydan, Abdallah Ibrahim to Pers. Representative (Oct. 7, 2004), available http://www.dod.mil/pubs/foi/operation_and_plans/Detainee/csrt_arb/000300000399.pdf.

${ }^{52}$ U.S. Customs and Border Patrol, U.S. Dep'T of Homeland Sec., Terrorist ORGANIZATION REFERENCE GUIDE (2004), available at www.cj.msu.edu/ outreach/wmd/terror_reference.doc.

${ }^{53} I d$.
} 
terrorist organizations," as designated by the secretary of state, and thirty-eight "other terrorist groups," compiled from other sources.

Comparing the Combatant Status Review Board's list of seventyfour organizations that evidenced the detainee's link to al Qaeda and / or the Taliban, only $22 \%$ of those organizations are included in the Terrorist Organization Reference Guide. Further, the Reference Guide describes each organization, quantifies the organization's strength, locations or areas of operation, and sources of external aid. Based on these descriptions of the organizations, only $11 \%$ of all organizations listed by the Combatant Status Review Board as proof of links to al Qaeda or the Taliban are identified as having any links to al Qaeda or the Taliban in the Terrorist Organization Reference Guide. Further, only $8 \%$ of the organizations identified by the Combatant Status Review Board even target U.S. interests abroad.

The evidence against 39\% of the detainees rested in part upon the possession of Kalashnikov rifles. Possession of a rifle in Afghanistan does not distinguish a peaceful civilian from any terrorist. The "Kalashnikov culture" permeates both Afghanistan and Pakistan. ${ }^{55}$ As the Pakistani Mission to the United Nations noted:

Our economy has been suffering and continues to suffer because of the situation in Afghanistan. Rampant terrorism as well as the culture of drugs and guns-that we call the "Kalashnikov Culture"-tearing apart our social and political fabric-was also a direct legacy of the protracted conflict in Afghanistan. ${ }^{56}$

This was evident not merely to the Pakistani foreign minister, but also to American college students touring Afghanistan. "There is a big Kalashnikov-rifle culture in Afghanistan: . . . I was somewhat bemused when I walked into a restaurant this afternoon to find Kalashnikovs hanging in the place of coats on the rack near the entrance....,57

${ }^{54} I d$.

55 Afghanistan is also the world's center for unaccounted weapons; thus, there is no exact count on the number of weapons in circulation. Arms experts have estimated that "there are at least 10 million small arms within Afghanistan." WATCHLIST ON Children AND ARMed Conflict, Issue 1: AfGHANistan 5 (2001), available at http://watchlist.org/reports/pdf/afghanistan.report.pdf. The arms flow has included Soviet weapons funneled into the country during the 1979 invasion, arms from Pakistan supplied to the Taliban, and arms from Tajikistan that equipped the Northern Alliance. Id.

${ }_{56}$ Shamshad Ahmad, Permanent Representative of Pak. to United Nations, Statement to the United Nations on Afg., Pakistan (Dec. 20, 2001), available at http://www.un.org/spanish/aboutun/organs/ga/56/verbatim/a56pv89e.pdf.

${ }_{54}$ Barnaby Hall, Letters from Afghanistan, 89 DUKE MAG. 1 (2002), available at http:/ / www.dukemagazine.duke.edu/dukemag/issues/111202/afghan1.html. 
The government treated one's presence at a "guest house" as evidence supporting a finding that one was an enemy combatant. ${ }^{58}$ The evidence against $27 \%$ of the detainees included their residences while traveling through Afghanistan and Pakistan. But, stopping at such facilities is common for all people traveling in the area. In the region, the term "guest house" refers simply to a form of travel accommodation. $^{59}$ Numerous travel and tourism agencies, such as Worldview Tours, South Travels, and Adventure Travel include overnight stays at local guest houses and rest houses on their tour package itineraries and lists of accommodations, which are marketed to western tourists. ${ }^{60}$ Guest houses and rest houses typically offer budget rates and breakfast. American travel agents advise American tourists to expect to stay in guest houses in either country.

In one case, the government cited the detainee's possession of a Casio watch or the wearing of olive drab clothing as evidence that the detainee was an enemy combatant. ${ }^{61}$ No basis was given to explain why such evidence makes the detainee an enemy combatant.

\section{CONTINUEd DETENTION OF NON-COMBATANTS}

The most well recognized group of individuals who were held to be enemy combatants and for whom summaries of evidence were

\footnotetext{
${ }_{58}$ See, e.g., Memorandum from OIC, CSRT on Summary of Evidence for Combatant Status Review Tribunal-Aleh, Ali Bin Ali to Pers. Representative (Oct. 20, 2004), available

http://www.dod.mil/pubs/foi/operation_and_plans/Detainee/csrt_arb/000500000599.pdf.

${ }^{59}$ See Stacy Perman, Aiding Afghanistan with Style, Bus. WK. (June 7, 2005), http://www.businessweek.com/smallbiz/content/jun2005/sb2005067_5111_sb013.h $\mathrm{tm}$ (describing an Afghani woman named Mahboba who hopes to open a chain of women's guest houses while gaining assistance from participation in a program sponsored by the Business Council for Peace); see also Paul Tough, The Reawakening, N.Y. Times, Sept. 25, 2005, § 6 (Magazine), at 98 (describing the guest houses in which the reporter and his girlfriend stayed while he explored the budding tourism industry in Afghanistan).

${ }^{60}$ See Adventure Holiday in Pakistan: Budget Hotels and Guesthouses, SOUTHTRAVELS.COM, http://www.south travels.com/asia/pakistan/index.html (last visited Sept. 28, 2011); Introduction, ADVENTURE TRAVEL, http://www.adventure-touroperator.com/main.html (last visited Sept. 28, 2011); Services Along the Silk Road: Accommodations, WORLDVIEW TOURS, http://www.worldviewtours.com/service/accomodation.htm (last visited Sept 28, 2011).

${ }^{61}$ See Unclassified Summary of Basis for Tribunal Decision at 1, Al Edah v. Bush, No. 05-280 (D.D.C. July 13, 2005), available at http://www.dod.mil/pubs/foi/operation_and_plans/Detainee/csrt_arb/publicly_fil ed_CSRT_records_191-236.pdf.
} 
available are the Uighurs. ${ }^{62}$ These individuals are Chinese Muslims who fled persecution in China to neighboring countries. ${ }^{63}$ The detainees then fled to Pakistan when Afghanistan came under attack by the United States after September 11, 2001. ${ }^{64}$ The Uighurs were arrested in Pakistan and turned over to the United States. ${ }^{65}$ The United States detained at least two dozen Uighurs ${ }^{66}$ found in Afghanistan and Pakistan at Guantánamo Bay, Cuba. The government originally determined that these men were enemy combatants, just as the government determined for all of the other detainees. The government subsequently decided and publicly conceded that many of the Uighur detainees in Guantánamo Bay were wrongly found to be enemy combatants and should no longer be detained. ${ }^{67}$

Just how many more of the detainees were wrongly found to be enemy combatants remains to be seen. The evidence that satisfied the government that the Uighurs were enemy combatants paralleled the evidence against the other detainees-but the evidence against the Uighurs was sometimes even stronger.

The evidence against the Uighurs paralleled the evidence against the other detainees in that the Uighurs:

62 Uighurs, a Turkic ethnic minority of eight to twelve million people primarily located in the northwestern region of China and in some parts of Kyrgyzstan and Kazakhstan, face political and religious oppression at the hands of the Chinese government. The Congressional Human Rights Caucus of the United States House of Representatives has received several briefings on these issues, including the information that the People's Republic of China "continues to brutally suppress any peaceful political, religious, and cultural activities of Uighurs, and enforce a birth control policy that compels minority Uighur women to undergo forced abortions and sterilizations." U.S. Comm'n on Int'l Religious Freedom, Briefing for Congressional Human Rights Caucus (Feb. 20, 2006) (on file with author); see Robin Wright, Chinese Detainees Are Men Without a Country, WASH. Post, Aug. 24, 2005, at A1 (noting that in response to oppression by the Chinese government, many Uighurs fled to surrounding countries such as Afghanistan and Pakistan).

${ }^{63}$ World $\mathcal{E}^{2}$ Nation Update: At Home, NewSDAY, June 5, 2008, at A33.

${ }^{64}$ Id.

${ }^{65}$ Uighur Detainee Seeks to Stay in Guantanamo-To Mind Bother, IRISH TIMES, Sept. 29, 2009 , at 12.

${ }^{66}$ Uighurs in Guanatanamo, Uighur HuM. RTS. Project, http://uhrp.org/categories/Issues/Uyghurs-in-Guantanamo/?Page=9 (last visited Oct. 5, 2011).

${ }^{67}$ Since this Report's initial publication, the Uighurs' habeas petitions have been granted. See William Glaberson, Judge Orders 17 Detainees at Guantánamo Freed, N.Y. $\begin{array}{lll}\text { Times, } & \text { Oct. } & \text { 2008, }\end{array}$ http://www.nytimes.com/2008/10/08/washington/08detain.html. Subsequently, however, the Court of Appeals for the D.C. Circuit "unanimously overturned [the] judge's order that would have freed" the seventeen detainees. William Glaberson, Appeals Court Stops Release of 17 Detainees in U.S., N.Y. TIMES, Feb. 19, 2009, at A19. 
- were Muslims; ${ }^{68}$

- were in Afghanistan; ${ }^{69}$

- associated with unidentified individuals or groups; ${ }^{70}$

- $\quad$ were trained to use Kalashnikov rifles; ${ }^{71}$

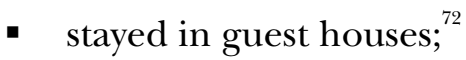

- were captured in Pakistan; ${ }^{73}$ and

- were captured by bounty hunters. ${ }^{74}$

If such evidence was insufficient to detain these persons as "enemy combatants," the data analyzed by this Report suggests that many other detainees should not have been classified as "enemy combatants." The detainees were afforded no meaningful opportunity to test the government's evidence against them. Some of them remain incarcerated.

${ }^{68}$ See, e.g., Memorandum from OIC, CSRT on Summary of Evidence for Combatant Status Review Tribunal-Asam, Zakirjan to Pers. Representative (Dec. 6. 2004), available

http://www.dod.mil/pubs/foi/operation_and_plans/Detainee/csrt_arb/000500000599.pdf.

${ }^{69}$ Id.

${ }^{70}$ See, e.g., Memorandum from OIC, CSRT on Summary of Evidence for Combatant Status Review Tribunal-Mamut, Abdul Helil to Pers. Representative (Sept. 16 2004), available http://www.dod.mil/pubs/foi/operation_and_plans/Detainee/csrt_arb/000300000399.pdf.

${ }^{71}$ See, e.g., Abbas, Summary, supra note 25.

72 See, e.g., Memorandum from OIC, CSRT on Summary of Evidence for Combatant Status Review Tribunal-Abdul Rahman, Abdul Ghappar to Pers. Representative (Oct. 29 2004), available at http://www.dod.mil/pubs/foi/operation_and_plans/Detainee/csrt_arb/000300000399.pdf.

73 See, e.g., id.

${ }^{74}$ See Louisa Lim, Tiny Island to Take 17 Guantanamo Detainees, NAT'L PUB. RADIO (June 10, 2009), http:/ /www.npr.org/templates/story/story.php?storyId=105188932. 